\title{
Preliminary Results of the National Bureau of Standards Radio and Ionospheric Observations During the Inter- national Geophysical Year
}

\author{
David M. Gates
}

(March 2, 1959)

\begin{abstract}
A review is given of the activities of the National Bureau of Standards during the International Geophysical Year. The equipment used on each project is described and preliminary results of the observations are given. The following areas of research are discussed: (1) World Warning Agency, (2) Ionospheric Vertical Sounding Stations, (3) VHF Propagation, (4) VHF Equatorial Forward Scatter, (5) Radio Noise Network, (6) Radio Satellite Observations, (7) Airglow Observations, and (8) World Data Center for Airglow and Ionosphere.
\end{abstract}

\section{Introduction}

The International Geophysical Year program was the greatest single international collaborative research effort ever devised by man to probe the properties of the planet earth from the depths of the oceans to the domain of interplanetary space. As a part of this program, the scientists of the Central Radio Propagation Laboratory, of the National Bureau of Standards in Boulder, Colorado, undertook a vast expansion of their radio research efforts in order to contribute to this international program and to take advantage of the many different simultaneous measurements being made throughout the world. Although most of the efforts were of a worldwide synoptic character, it was important that certain selected specialized experiments be carried out to coincide with the overall effort. The NBS experimental program, during the IGY, ranged from the large synoptic network of ionospheric vertical soundings stations to selected experiments concerned with equatorial forward scatter, sporadic- $E$, radio noise, night airglow and observations on satellite signals. This article is a brief summary of some of these projects at NBS and a preliminary report concerning some of the results available at this time.

Since the IGY was selected to coincide with a period of maximum activity in the solar atmosphere, it was essential that a close watch on the sun be maintained throughout this period. The solar patrols consisted of visual, optical, photographic, photometric, and radio observations of the sun throughout every minute of the IGY period. The IGY World Warning Agency headed by R. C. Moore at the NBS station at Fort Belvoir, Virginia, was designated to process and filter these data, to maintain a running account of the "state of the sun", and to alert the scientists of the world to periods of unusual solar activity. At times, during those Alerts, Special World Intervals were declared thereby accelerating scientific observations throughout the world. During the entire IGY period 21 Special World Intervals
(SWI's) totaling 45 days were declared. During 16 of these SWI's 18 geomagnetic disturbances occurred; two of the disturbances being followed by second storms. Only four SWI's totaling 7 days were not followed by disturbances and one interval of 1-day duration was initiated after the storm had started. Approximately two-thirds of the severe geomagnetic disturbances were predicted and onethird were missed. However, previous to the IGY it was thought that if two major storms were forecast during the entire IGY period this would represent adequate success.

\section{IGY Ionospheric Vertical Sounding Observations by NBS}

During the International Geophysical Year a large network of vertical incidence ionospheric sounding stations (about 150) was placed in operation throughout the world. Since the vertical incidence pulse technique is one of the most reliable methods for obtaining a measure of the electron density and the electron density profile of the ionosphere, it was important to establish stations of this nature at as many strategic locations as possible. Prior to the IGY the National Bureau of Standards operated 20 stations throughout the world, while during the IGY they operated directly or cooperated with other agencies in the operation of 34 stations. Table 1 lists these stations, gives the geographic and geomagnetic coordinates, the angle of magnetic dip, and lists the equipment used at each station. All stations were on a 15-min basic-sounding schedule. Much of the reduction of the data was done at the stations, but all data sent to Boulder on a monthly or bimonthly basis was reviewed in order to assure smooth and consistent operation of the program. Engineering teams were periodically sent to the stations in order to install any modification of the equipment and to assist where needed. The vertical incidence program at the National Bureau of Standards has been under the direction of $\mathrm{A} . \mathrm{H}$. Shapley, R. W. Knecht, and H. G. Sellery. 
TABLE 1. Vertical sounding stations operated as part of the NBS observational program during the IGY

\begin{tabular}{|c|c|c|c|c|c|c|c|c|}
\hline \multirow{2}{*}{ Station } & \multirow{2}{*}{$\begin{array}{l}\text { Equip- } \\
\text { ment }\end{array}$} & \multicolumn{2}{|c|}{$\begin{array}{l}\text { Geographic } \\
\text { coordinates }\end{array}$} & \multicolumn{2}{|c|}{$\begin{array}{l}\text { Geomagnetic } \\
\text { coordinates }\end{array}$} & \multirow{2}{*}{$\begin{array}{l}\text { Dip } \\
\text { angle }\end{array}$} & \multirow{2}{*}{$\begin{array}{l}\text { Time } \\
\text { used }\end{array}$} & \multirow{2}{*}{ Operated by } \\
\hline & & lat. & long. & lat. & long. & & & \\
\hline 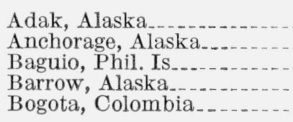 & $\begin{array}{l}\mathrm{C}-3 \\
\mathrm{C}-3 \\
\mathrm{C}-2 \\
\mathrm{C}-2 \\
\mathrm{C}-4\end{array}$ & $\begin{array}{ll}\text { N51 } & 54 \\
\text { N61 } & 14 \\
\text { N16 } & 25 \\
\text { N71 } & 08 \\
\text { N4 } & 32\end{array}$ & $\begin{array}{lll}\text { W176 } & 39 \\
\text { W149 } & 53 \\
\text { E120 } & 36 \\
\text { W156 } & 48 \\
\text { W74 } & 15\end{array}$ & $\begin{array}{l}\text { N } 47.3 \\
\text { N60.9 } \\
\text { N51.1 } \\
\text { N68.4 } \\
\text { N15.9 }\end{array}$ & $\begin{array}{l}\mathrm{E} 240.0 \\
\mathrm{E} 258.1 \\
\mathrm{E} 189.3 \\
\mathrm{E} 241.2 \\
\mathrm{E} 354.5\end{array}$ & $\begin{array}{l}64 \\
74 \\
18 \\
81 \\
32\end{array}$ & $\begin{array}{l}180 \mathrm{~W} \\
150 \mathrm{~W} \\
120 \mathrm{E} \\
150 \mathrm{~W} \\
75 \mathrm{~W}\end{array}$ & $\begin{array}{l}\text { Signal Corps. } \\
\text { NBS. } \\
\text { Manila Observatory } \\
\text { NBS. } \\
\text { Geophys. Inst. Colombian Andes. }\end{array}$ \\
\hline $\begin{array}{l}\text { Byrd, Antarctica } \\
\text { Cape Hallett, Antarctica. } \\
\text { Chiclayo, Peru } \\
\text { Chimbote, Peru. } \\
\text { Concepcion, Chile......... }\end{array}$ & $\begin{array}{l}\mathrm{C}-3 \\
\mathrm{C}-4 \\
\mathrm{C}-3 \\
\mathrm{C}-4 \\
\mathrm{C}-4\end{array}$ & $\begin{aligned} \text { S80 } & \\
\text { S72 } & 25 \\
\text { S6 } & 48 \\
\text { S9 } & 04 \\
\text { S36 } & 35\end{aligned}$ & $\begin{array}{ll}\text { W120 } \\
\text { E170 } & 55 \\
\text { W79 } & 49 \\
\text { W78 } & 35 \\
\text { W72 } & 59\end{array}$ & $\begin{array}{l}\text { S70 } 36 \\
\text { S74.6 } \\
\text { N4.4 } \\
\text { N2.2 } \\
\text { S25.3 }\end{array}$ & $\begin{array}{l}\text { E336 01 } \\
\text { E279.0 } \\
\text { E349.2 } \\
\text { E350.4 } \\
\text { E356.5 }\end{array}$ & $\begin{array}{r}-75 \\
-84 \\
10 \\
6 \\
-35\end{array}$ & $\begin{array}{c}120 \mathrm{~W} \\
165 \mathrm{E} \\
75 \mathrm{~W} \\
75 \mathrm{~W} \\
75 \mathrm{~W}\end{array}$ & $\begin{array}{l}\text { NBS. } \\
\text { New Zealand. } \\
\text { Geophys. Inst. Huancayo. } \\
\text { Geophys. Inst. Huancayo. } \\
\text { Univ. of Concepcion. }\end{array}$ \\
\hline $\begin{array}{l}\text { Ellsworth, Antarctica } \\
\text { Ft. Belvoir, Va. } \\
\text { Ft. Monmouth, N.J....... } \\
\text { Fairbanks, Alaska. } \\
\text { Godhavn, Greenland...... }\end{array}$ & $\begin{array}{l}\mathrm{C}-4 \\
\mathrm{C}-3 \\
\mathrm{C}-4 \\
\mathrm{C}-3 \\
\mathrm{C}-3\end{array}$ & $\begin{aligned} & \text { S77 } 43 \\
& \text { N38 } 44 \\
& \text { N40 23 } \\
& \text { N64 } 51 \\
& \text { N69 } 16\end{aligned}$ & $\begin{array}{rl}\text { W41 } & 08 \\
\text { W77 } & 08 \\
\text { W74 } & 08 \\
\text { W147 } & 50 \\
\text { W } 53 & 30\end{array}$ & $\begin{array}{l}\text { S66 } 56 \\
\text { N50.1 } \\
\text { N51.7 } \\
\text { N64.7 } \\
\text { N79.9 }\end{array}$ & $\begin{array}{l}\text { E14 } 42 \\
\text { E350.1 } \\
\text { E353.9 } \\
\text { E256. } \\
\text { E32.5 }\end{array}$ & $\begin{array}{l}-68 \\
71 \\
71.5 \\
77 \\
81\end{array}$ & $\begin{array}{r}45 \mathrm{~W} \\
75 \mathrm{~W} \\
75 \mathrm{~W} \\
150 \mathrm{~W} \\
45 \mathrm{~W}\end{array}$ & $\begin{array}{l}\text { NBS. } \\
\text { NBS. } \\
\text { Signal Corps. } \\
\text { Univ. of Alaska. } \\
\text { Danish URSI Comm. }\end{array}$ \\
\hline $\begin{array}{l}\text { Grand Bahama Is., B.W.I } \\
\text { Huancayo, Peru.. } \\
\text { Fletcher's Ice Island } \\
\text { La Paz, Bolivia } \\
\text { Little America, Ant }\end{array}$ & $\begin{array}{l}\mathrm{C}-4 \\
\mathrm{C}-4 \\
\mathrm{C}-2 \\
\mathrm{C}-4 \\
\mathrm{C}-4\end{array}$ & $\begin{array}{l}\text { N26 } 40 \\
\text { S12 } 03 \\
\text { N85 } \\
\text { S16 } 29 \\
\text { S78 } 16\end{array}$ & $\begin{array}{rrr}\text { W78 } & 22 \\
\text { W75 } & 20 \\
\text { W100 } & \\
\text { W68 } & 03 \\
\text { W162 } & 28\end{array}$ & $\begin{array}{l}\text { N37. } \\
\text { S0. } 6 \\
\text { (Driff } \\
\text { S5. } 0 \\
\text { S74 } 08\end{array}$ & $\begin{array}{c}\text { E349.3 } \\
\text { E353. } 8 \\
\text { ting) } \\
\text { E0.9 } \\
\text { E312 } 04\end{array}$ & $\begin{array}{r}59 \\
2 \\
88 \\
-5 \\
-80.5\end{array}$ & $\begin{array}{r}75 \mathrm{~W} \\
75 \mathrm{~W} \\
75 \mathrm{~W} \\
60 \mathrm{~W} \\
165 \mathrm{~W}\end{array}$ & $\begin{array}{l}\text { Signal Corps. } \\
\text { Geophys. Inst. Huancayo. } \\
\text { Signal Corps. } \\
\text { University of San Andres. } \\
\text { NBS. }\end{array}$ \\
\hline $\begin{array}{l}\text { Maui, T.H } \\
\text { Natal, Brazil } \\
\text { Narsarssuak, Greenland } \\
\text { Okinawa, Ryu Kyu I. } \\
\text { Panama Canal Zone }\end{array}$ & $\begin{array}{l}\mathrm{C}-4 \\
\mathrm{C}-4 \\
\mathrm{C}-3 \\
\mathrm{C}-3 \\
\mathrm{C}-3\end{array}$ & $\begin{aligned} \text { N20 } & 50 \\
\text { S5 } & 20 \\
\text { N61 } & 11 \\
\text { N26 } & 19 \\
\text { N9 } & 23\end{aligned}$ & $\begin{array}{ll}\text { W156 } & 30 \\
\text { W35 } & 07 \\
\text { W45 } & 25 \\
\text { E127 } & 47 \\
\text { W79 } & 53\end{array}$ & $\begin{array}{l}\text { N20.8 } \\
\text { N4.2 } \\
\text { N71.2 } \\
\text { N15. } \\
\text { N20.6 }\end{array}$ & $\begin{array}{r}\text { E268.1 } \\
\text { E33.9 } \\
\text { E37. } \\
\text { E195. } \\
\text { E348. }\end{array}$ & $\begin{array}{r}38 \\
-2 \\
77 \\
37 \\
39\end{array}$ & $\begin{array}{c}150 \mathrm{~W} \\
30 \mathrm{~W} \\
45 \mathrm{~W} \\
135 \mathrm{E} \\
75 \mathrm{~W}\end{array}$ & $\begin{array}{l}\text { NBS. } \\
\text { Brazilian Navy. } \\
\text { Danish URSI Comm. } \\
\text { Signal Corps. } \\
\text { NBS. }\end{array}$ \\
\hline $\begin{array}{l}\text { Puerto Rico } \\
\text { Reykjavik, Iceland } \\
\text { San Francisco, Calif.-. } \\
\text { South Pole Station } \\
\text { St. Johns, Newfoundland.- }\end{array}$ & $\begin{array}{l}\mathrm{C}-3 \\
\mathrm{C}-2 \\
\mathrm{C}-3 \\
\mathrm{C}-3 \\
\mathrm{C}-3\end{array}$ & $\begin{array}{ll}\text { N18 } & 30 \\
\text { N64 } & 08 \\
\text { N37 } & 26 \\
\text { S90 } \\
\text { N47 } & 37\end{array}$ & $\begin{array}{rr}\text { W67 } & 12 \\
\text { W21 } & 47 \\
\text { W122 } & 10 \\
\text { W } 52 \quad 42\end{array}$ & $\begin{array}{l}\text { N30. } 0 \\
\text { N70.2 } \\
\text { N43. } \\
\text { S78 30 } \\
\text { N58.5 }\end{array}$ & $\begin{array}{r}\mathrm{E} 2.0 \\
\mathrm{E} 69.8 \\
\mathrm{E} 298.4 \\
0 \\
\mathrm{E} 21.4\end{array}$ & $\begin{array}{r}51 \\
74 \\
62 \\
-75 \\
72.5\end{array}$ & $\begin{array}{c}60 \mathrm{~W} \\
15 \mathrm{~W} \\
120 \mathrm{~W} \\
0 \\
60 \mathrm{~W}\end{array}$ & $\begin{array}{l}\text { NBS. } \\
\text { Iceland Post \& Telegraph. } \\
\text { Stanford University. } \\
\text { NBS. } \\
\text { Signal Corps. }\end{array}$ \\
\hline $\begin{array}{l}\text { Talara, Peru } \\
\text { Thule, Greenland } \\
\text { White Sands, N. Mex } \\
\text { Wilkes, Antaretica..... }\end{array}$ & $\begin{array}{l}\text { C-3 } \\
\text { C-4 } \\
\text { C-3 } \\
\text { C-4 }\end{array}$ & $\begin{array}{r}\text { S4 38 } \\
\text { N76333 } \\
\text { N32 24 } \\
\text { S66 25 }\end{array}$ & $\begin{array}{rr}\text { W81 } & 18 \\
\text { W68 } & 50 \\
\text { W106 } & 52 \\
\text { E110 } & 27\end{array}$ & $\begin{array}{l}\text { N6. } 6 \\
\text { N88 } 03 \\
\text { N41.2 } \\
\text { S77.9 }\end{array}$ & $\begin{array}{l}\text { E347.7 } \\
\text { E1 08 } \\
\text { E316.4 } \\
\text { E178. } 8\end{array}$ & $\begin{array}{r}13 \\
86 \\
60 \\
-81\end{array}$ & $\begin{array}{c}75 \mathrm{~W} \\
75 \mathrm{~W} \\
105 \mathrm{~W} \\
105 \mathrm{E}\end{array}$ & $\begin{array}{l}\text { Geophys. Inst. Huancayo. } \\
\text { Signal Corps. } \\
\text { Signal Corps. } \\
\text { NBS. }\end{array}$ \\
\hline
\end{tabular}

\subsection{Equatorial Close-Spaced Chain}

Interesting results have come from the ionospheric soundings from the equatorial close-spaced chain of stations in South America [1]. ${ }^{1}$ These stations were located at Talara, Chiclayo, Chimbote, Huancayo, and La Paz. Their geographic and geomagnetic coordinates are given in table 1 . The hourly ionograms for 15 October 1957 were reduced to true height profiles of electron density using the Budden matrix method [2]. In figure 1 the variation of

1 Figures in brackets indicate the literature references at the end of this paper.

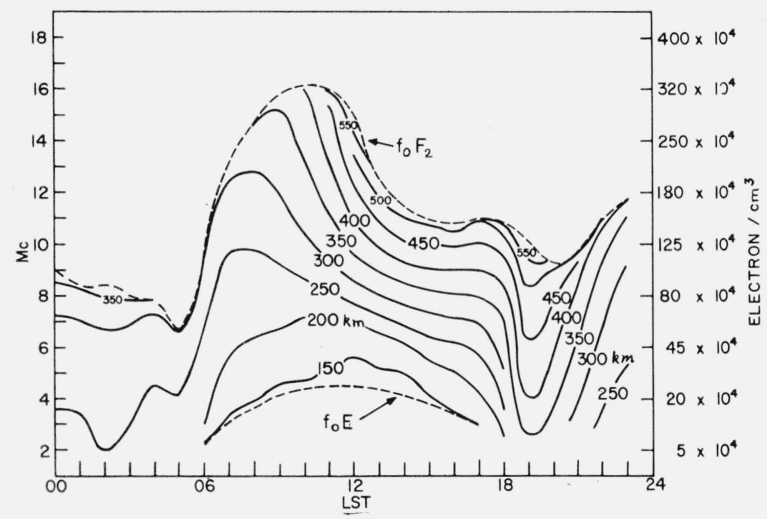

Figure 1. Electron density at fixed heights for huancayo. October 15,1957 . electron density at fixed heights is shown for the 24hr period at Huancayo. These curves are typical of the other four stations as well. The sharp increase at sunrise in the electron density should be noted as well as the fact that the intermediate levels attain a maximum electron density earlier than the higher levels. In addition, the lower levels exhibit a Chapman-like behavior, i.e., electron density proportional to the square root of the cosine of the sun's zenith angle. Particularly notable is the abrupt rise in height of the electron density at sunset, an effect considerably larger than expected from straight recombination alone.

Equatorial sporadic E, which occurs during most daylight hours throughout the year at stations near the equator, appears on the ionogram as a diffuse trace often extending $20 \mathrm{~km}$ or more in height and seldom blanketing the $F$ region echoes. The extent of the equatorial sporadic $E$ can readily be ascertained from figure 2 which shows the percentage occurrence as a function of the magnetic dip of the station. Eleven months of data (July 1957 through May 1958) were averaged to obtain the percentages for Talara, Chiclayo, Chimbote, and Huancayo, however, only one month of data was available for La Paz. From the curve it is clear that this form of sporadic $E$ is a very distinctive equatorial phenomena, and that it occurs with a frequency greater than 35 percent only within a belt spread about $5.5^{\circ}$ to either side of the geomagnetic equator and has dropped to a frequency of only 5 percent by $8^{\circ}$ from 


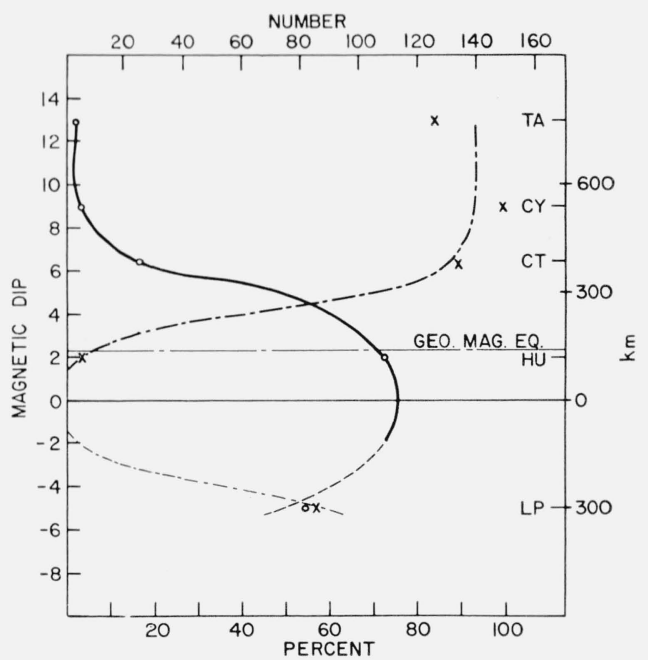

Figure 2. Percentage occurrence of Es-q along the equatorial close-spaced chain, 06-(- and total number of hourly soundings showing prominent blanketing by Es, i.e. fbEs $>$ $5 \mathrm{Mc}$ (—— - - July $1957^{2}$ through May 1958. TA-Talara, CY-Chiclayo, CT-Chimbote Hu-Huancayo, LPDaPaz.

July 1957 through May 1958. TA=Talara, CY=Chiclayo, CT=Chimbote $\mathrm{HU}=$ Huancayo, and LP $=\mathrm{LaPaz}$.

the geomagnetic equator. Although earlier workers $[3,4]$ had suggested a somewhat wider belt for equatorial sporadic $E$, recent IGY experiments on the earth's magnetic field in the vicinity of the geomagnetic equator by S. E. Forbush, as recently reported by $\mathrm{H}$. Odishaw [5], give a similar width to the equatorial electrojet. Note that the scale along the right-hand vertical axis represents distance perpendicular to the contours of equal dip and not distance between stations.

Although the equatorial sporadic $E$ persisted throughout most days of the year, occasionally it would disappear suddenly for periods of minutes to hours in the early afternoon. Matsushita [6] has established a definite lunar dependence for this effect, which suggested that a similar relationship might hold true for the time of first appearance for equatorial sporadic $E$, since these times varied from as early as 0600 and as late as 1000 . In contrast, the late afternoon disappearance occurred regularly between 1730 and 1830. In order to test this hypothesis the data for Huancayo from May 1957 to April 1958 were divided into the three seasons (equinox and June and December solstice). Three day running means of the times of first appearance were computed and plotted against the lunar phase as shown in figure 3. A lunar correlation is clearly evident in the equinoctial and December-solstice curves with equatorial sporadic $E$ appearing earlier in the morning on days of new and full moon. The data for the June solstice do not suggest quite as strong a lunar control, however, as more data become available the scatter of the points may be reduced. Matsushita had explained the lunar effect for the midday disappearance in terms of ionospheric electric currents. He assumed that the equatorial sporadic $E$ was caused by the vertical drifting of

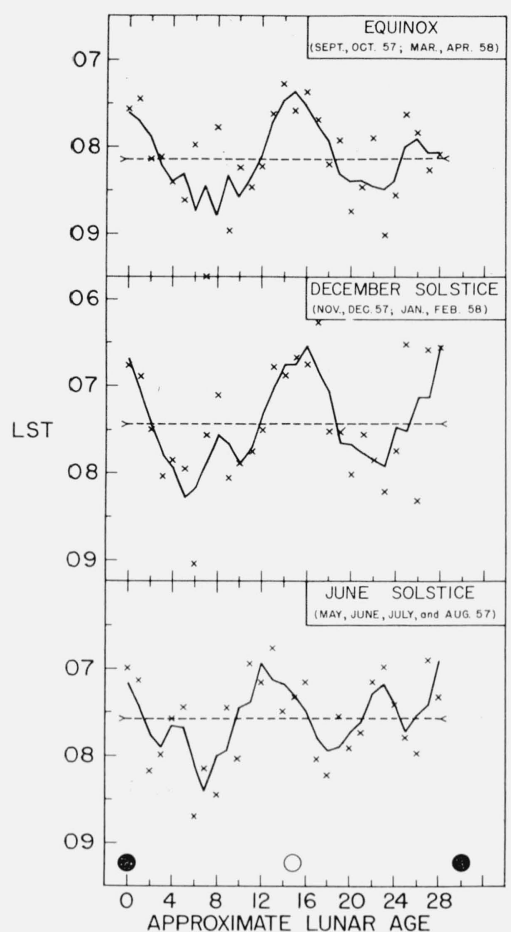

FIGURE 3. Lunar influence on time of first appearance of Es-q at Huancayo.

Three-day running mean plotted.

electrons in the eastward-flowing electric current and that the lunar tides induce a westward-flowing counter-current which reduces the strength of the sporadic E. Pursuing these arguments further, Knecht [7] of the Central Radio Propagation Laboratory points out that during the new and full moon the lunar-induced current adds an easterly flow to the already established solar induced easterly during the early morning hours, whereas during the first and third quarter the lunar tide counteracts the easterly solar current thus retarding the appearance of the sporadic $E$ in the morning. It would appear from these observations that Matsushita's hypothesis concerning the electron-current systems has been further verified.

\subsection{Electron Density Profiles along the $75^{\circ} \mathrm{W}$ Meridian}

A true height electron density analysis has been made for the following stations located near the $75^{\circ}$ W meridian: Chimbote and Talara, Bogota, Panama, Puerto Rico, Grand Bahama Island, and Fort Monmouth, New Jersey. The Budden matrix method was used with the assistance of the IBM 650 computer to reduce the ionogram data. Another computer program was used to interpolate the values of electron density at fixed heights, compute the height of the maximum and integrate the electron density up to $h_{\max }$. This research was carried out at NBS by J. W. Wright and G. H. Stonehocker.

The hourly ionograms from the seven stations were reduced to give true heights of reflection at frequency intervals of $0.2 \mathrm{Mc}$ from $1.8 \mathrm{Mc}$ to $f_{0} F_{2}$. 

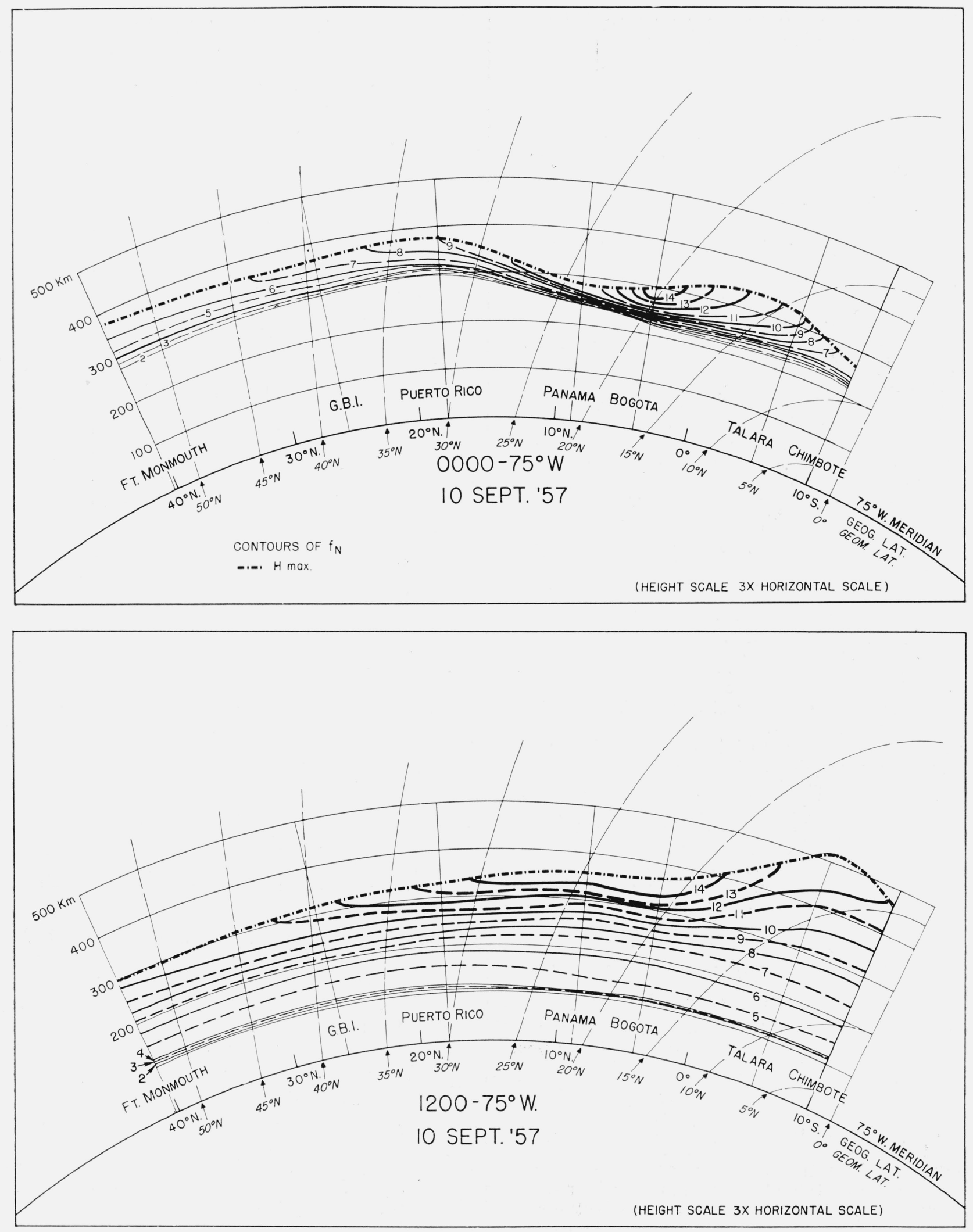

Figure 4. True height electron density profiles along 

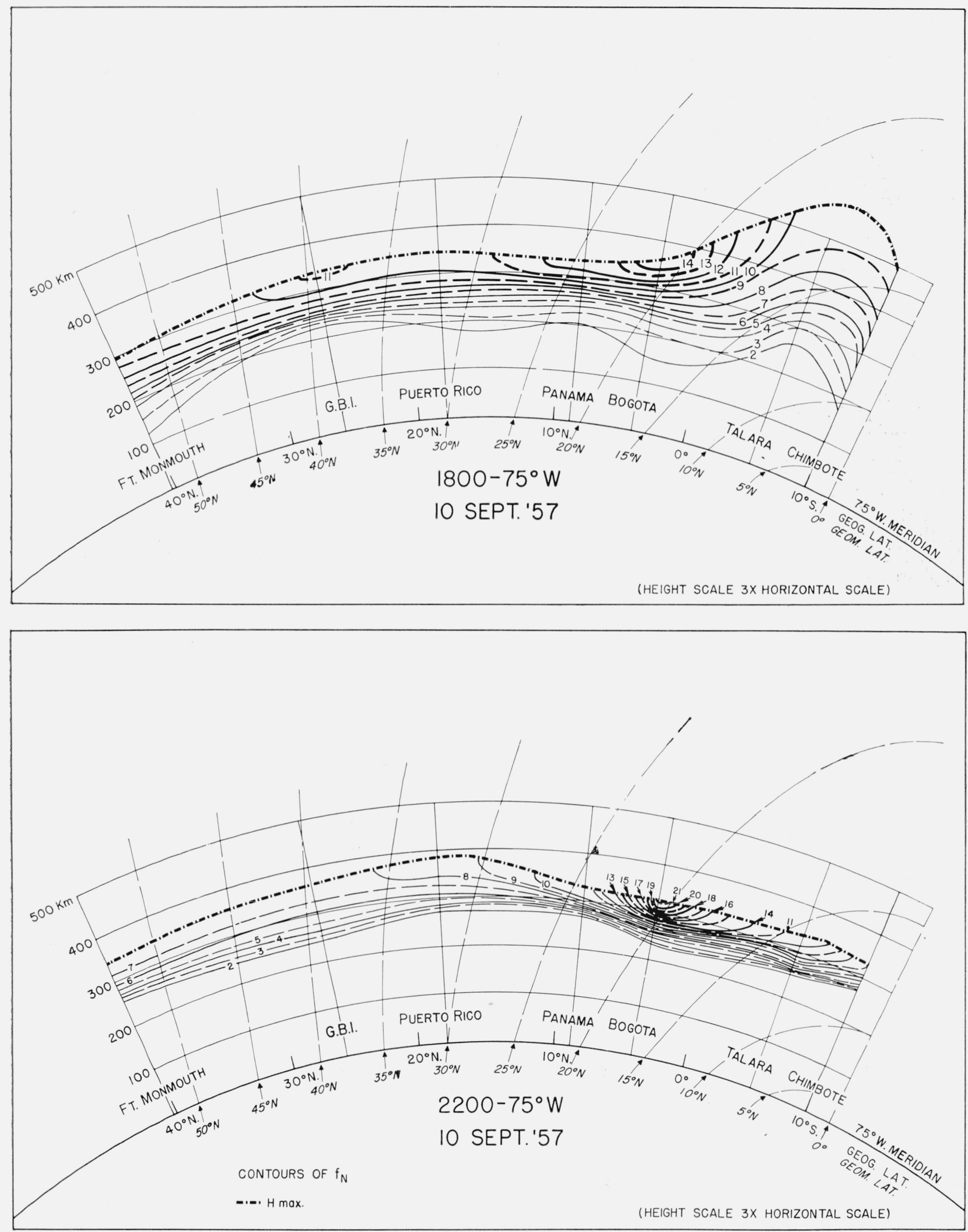

the $75^{\circ} \mathrm{W}$ meridian, between $40^{\circ} \mathrm{N}$ and $10^{\circ} \mathrm{S}$. 
A sample of the results, after interpolation, is shown in figure 4 for $0000,1200,1800$, and 2200 universal time (u.t.). Here contours of $f_{N}$, the plasma frequency, are shown on a height versus latitude plot. Similar plots have been made for every $2 \mathrm{hr}$ throughout the 24-hr period, but these suffice to illustrate the phenomena. Several of the usual ionospheric features show up in these diagrams, but the new and interesting feature concerns the increase in electron density over Bogota during the late evening hours and the bulge in the ionosphere which developes over the equator. It is possible that this bulge may be the result of some form of tidal action but at the moment it is not fully understood.

\subsection{Vertical Incidence Soundings from Antarctica}

For the first time during the IGY there was established on the Antarctic continent a sizeable network of ionospheric vertical incidence stations [8]. Of a total of approximately a dozen, the following five were operated by the U.S.: Pole, Byrd, Little America, Ellsworth, and Wilkes. The data reported here represent the first from high-latitude southern stations and the first ever obtained at either the North or South Pole. Prior to making these observations there was considerable question concerning the state of the ionosphere above the pole, whether the ionosphere could exist throughout the 6 -month period of darkness, whether diurnal variations existed in the polar winter ionosphere, and what the nature of the $f_{0} F_{2}$ variations over the Antarctic continent were like. The present data, representing the period June 1957 to May 1958, definitely supply the answers to some of these questions. Further data through January 1959 are now available but only the analysis of the earlier data will be presented here.

In figure 5 are shown, for five of the antarctic stations, the monthly median values of $f_{0} F_{2}$ plotted against time of day for each hour. For the Wilkes and Ellsworth stations, the normal temperate latitude behavior is seen with the diurnal variation reaching a maximum around midday. For the Little America and Byrd bases the maximum is reached during the evening hours and for the Pole there appears to be a weak diurnal variation with the maximum occurring in the early morning hours. It is curious indeed that the ionosphere over the pole in July has minimum $f_{0} F_{2}$ values which are greater than those over any other station. This is particularly surprising since throughout July the atmosphere above the pole is not illuminated below an altitude of about $450 \mathrm{~km}$. The summertime (December) $f_{0} F_{2}$ values exhibit relatively little diurnal variation as expected.

Typical winter and summer ionograms taken at the Pole station are shown in figure 6 . The wintertime-spread echo shown here is typical of magnet-

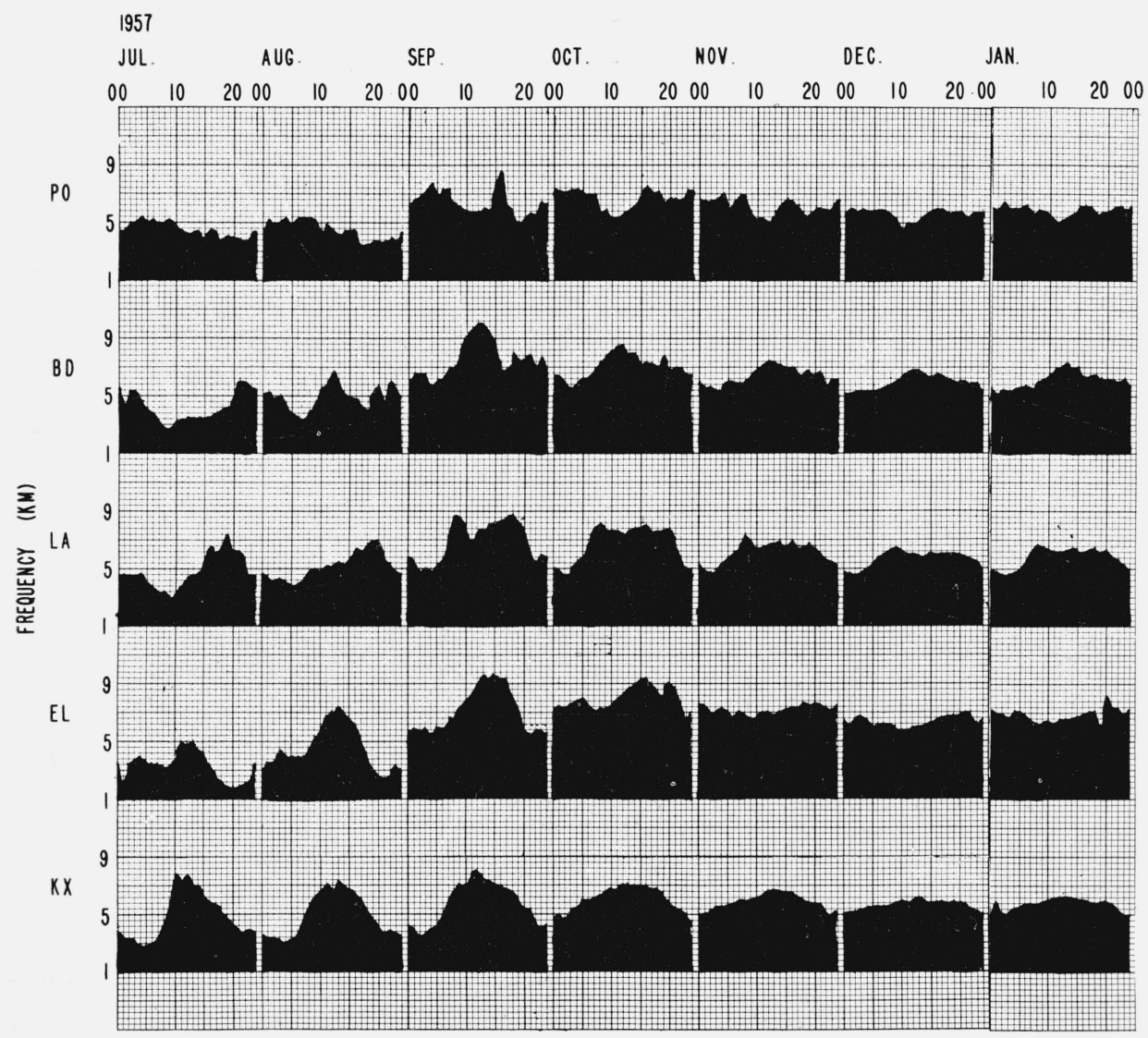

Figure 5. The monthly median $\mathrm{f}_{\mathrm{o}} \mathrm{F}_{2}$ for five antarctic stations. $\mathrm{PO}=\mathrm{Pole}, \mathrm{BD}=\mathrm{Bird}, \mathrm{LA}=$ Little America, $\mathrm{EL}=$ Ellsworth, $\mathrm{KX}=$ Wilkes . 


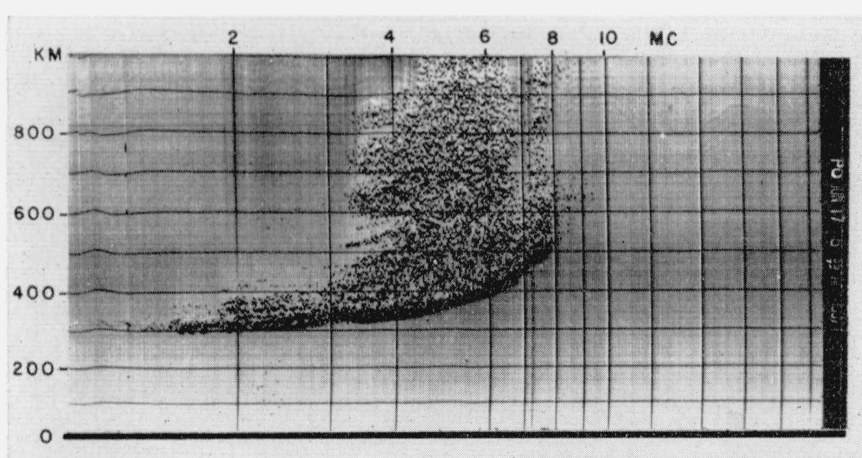

JUNE 17,1957

0535 U.T.

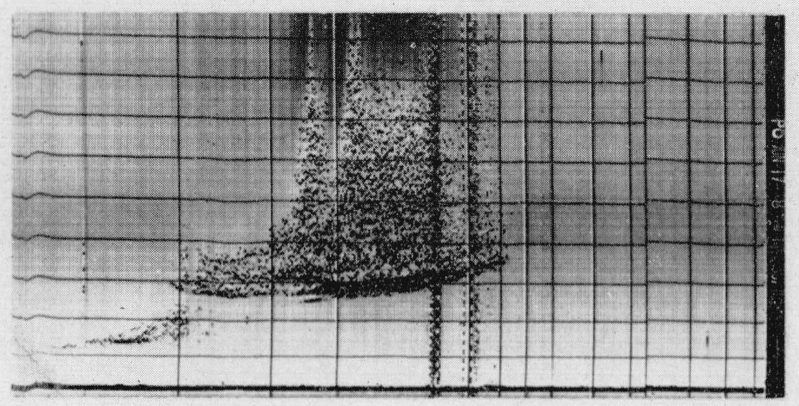

JUNE 17,1957

2020 U.T.

WINTER

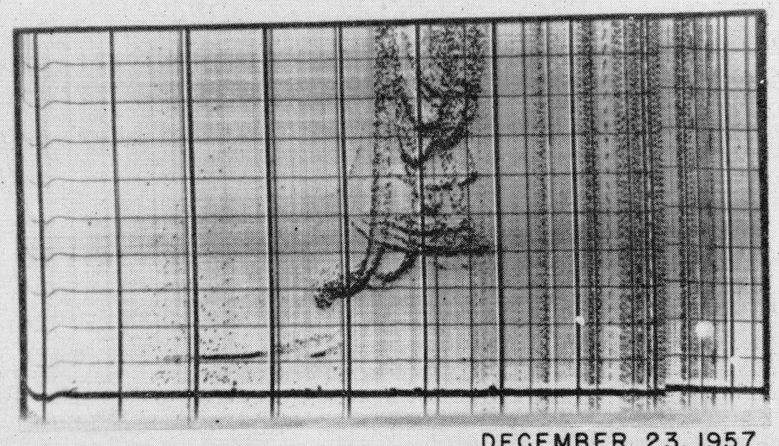

0000 U.T.

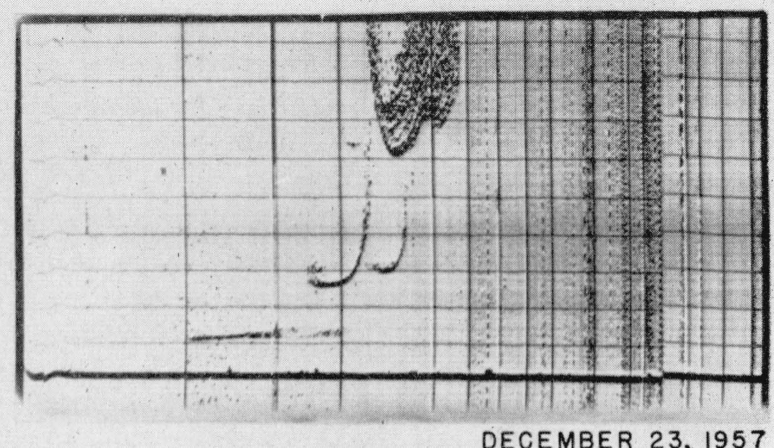

1200 U.T.

SUMMER

Figure 6. Typical winter and summer ionograms taken at the South Geographic Pole.

ically-undisturbed winter days. These soundings show that there is considerable ionization present as low as $250 \mathrm{~km}$. while the sun's rays do not strike below $450 \mathrm{~km}$ for July. Note also the appearance of the "night $E$ " on the 2020 ionogram. The summertime ionograms shown on the right are typical of this season at the Pole. Particularly noteworthy is the constancy throughout the day of the critical frequency for $E, F_{1}$, and $F_{2}$.

A more detailed picture of the monthly median values of $f_{0} F_{2}$ for each hour of the day for the period June 1957 through May 1958 is shown in figure 7. The winter months (June, July, August) have the lowest $f_{0} F_{2}$ values and appear to have a 24 -hr wave, whereas the equinox and summer values are higher and exhibit a $12-\mathrm{hr}$ variation. A harmonic analysis of the monthly median values of $f_{0} F_{2}$ for these data is shown in figure 8 for the 24-, 12-, 8- and 6-hr components. The 24-hr component shows the winter values occurring at 0600 u.t. to be $90^{\circ}$ out of phase with the summer values at approximately 0000 u.t. Magnetic noon (the time when the sun is in the meridian plane containing the geomagnetic pole and the geographic pole) occurs at 0500 u.t. thus suggesting that the $F$-layer density in the darkened part tends to reach a maximum during those hours when the auroral zone has the maximum amount of sun- light for that time of the year. The 12 -hr wave appears at 0400 and 1600 u.t. and the 8 -hr wave at 0730,1530 , and 2330 u.t. The 6 -hr wave appears indefinite.

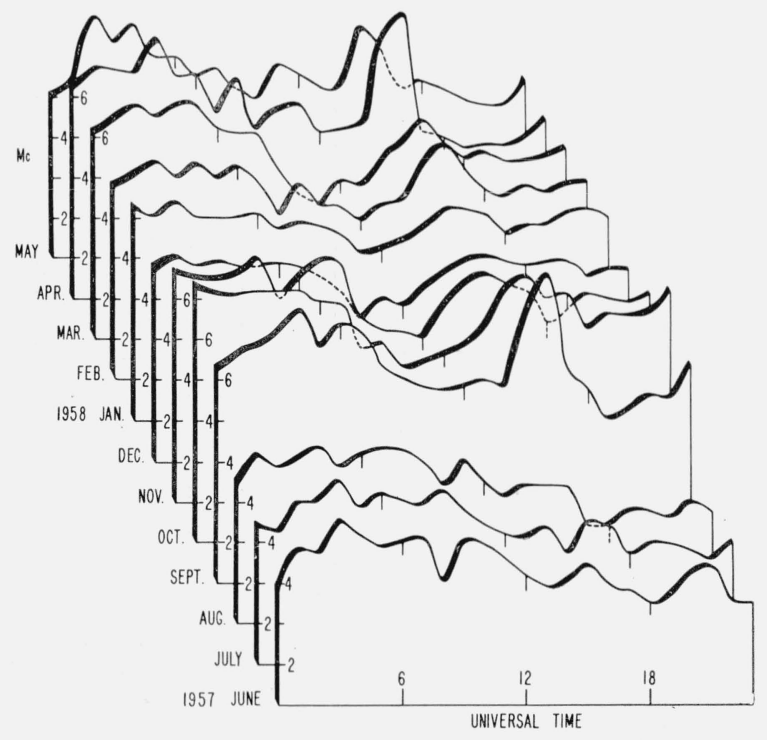

Figure 7. Monthly median $\mathrm{f}_{\mathrm{o}} \mathrm{F}_{2}$ for the South Pole Station. 


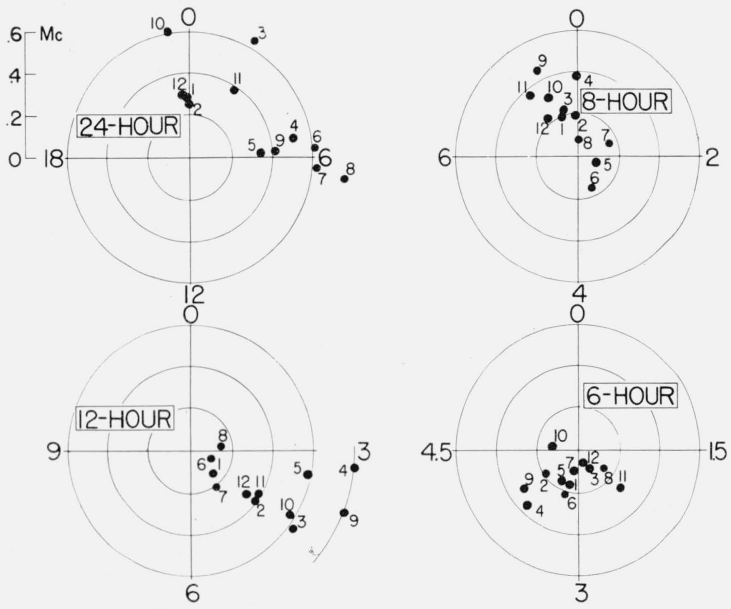

Figure 8. Harmonic analysis of $\mathrm{f}_{0} \mathrm{~F}_{2}$ for the South Pole. June 1957 through May 1958.

Although the analysis is still in progress it would appear that a significant diurnal variation occurs in the $f_{0} F_{1}$ and $f_{0} E$ during the polar summer. The principal wave seems to have a 24 -hr period showing a maximum at 2200 for $f_{0} F_{1}$ and at 1300 for $f_{0} E$. Even more striking though is the summertime, daylight behavior of $f_{0} F_{2}, f_{0} F_{1}$, and $f_{0} E$ monthly mean values for the Pole station when plotted against Zürich sunspot number as shown in figure 9.

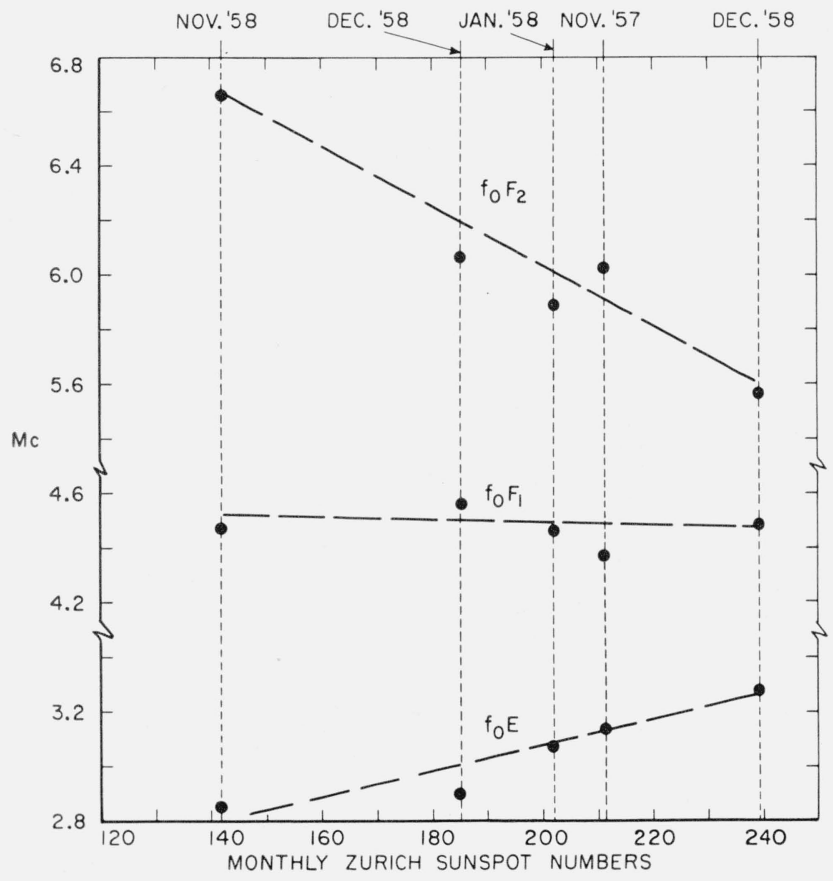

FIgURE 9. Means of the monthly medians for summer months at the Pole Station as a function of the monthly Zürich sunspot numbers.
It would appear from these results that over the Pole the $F_{2}$ region of the ionosphere becomes weaker, the $E$ region strengthens, and the $F_{1}$ region is relatively insensitive to increased solar activity. This occurs at the time of the year when the polar ionosphere is completely and continuously illuminated. By comparison, it is well known that at stations throughout the world, the critical frequency for each region of the ionosphere increases with increasing. sunspot number, since the increased solar activity produces an increase in ionizing radiation. Certainly it can be said that the data from the Pole station is unique in many respects. It raises several questions which unfortunately may not be answered until a much more detailed analysis is carried out. In certain instances further data will need to be obtained from the Pole station and careful comparison made with data from other Antarctic stations. Fortunately, the scientific observational program is continuing, although at a reduced level, in the Antarctica during 1959. Ionospheric soundings are being made at the Pole Station and at Byrd Base and it would be hoped that these measurements could be continued through the next minimum. of solar activity, if not indefinitely.

\section{VHF Propagation Comparison Between Far Eastern and American Circuits}

From VHF transmissions over circuits in the Far East there had been evidence of more enhancements due to sporadic- $E$ propagation than is observed in comparable latitudes in the rest of the world [3]. At times the signals were some $20 \mathrm{db}$ or more higher than over circuits in the United States. Usually propagation at VHF frequencies takes place by scatter from the lower ionosphere and occasionally by sporadic- $E$ enhancement. Because of the importance of sporadic $E$ to communications and because of the great difficulty scientists have had in understanding the mechanisms creating sporadic $E$ in the ionosphere it was particularly important to obtain detailed observations concerning this phenomenon in the Far East during the IGY. For this reason Dr. E. K. Smith, the project director, located one circuit in the Far East and a comparison circuit in the western hemisphere, each being a 2 -kw narrowband CW system operating over approximately an 800 -mile path at $50 \mathrm{Mc}$.

The Far Eastern circuit extended between the Voice of America relay stations at San Fernando (Poro Point), La Union, Luzon, Philippine Islands and Onna, Okinawa, on $49.84 \mathrm{Mc}$. An additional transmitter located at Okuma, Okinawa, produced 49.68-Mc signals which were received by the Japanese Radio Research Laboratories at Hiraiso and Yonago, Japan. In the western hemisphere a similar circuit was set up on 49.76 Mc between the CRPL field station at Margarita, Panama Canal Zone, and the U.S. Naval Base at Guantanamo Bay, Cuba. Late 
in the IGY an additional circuit was installed between the Canal Zone and Guayaquil, Ecuador, in cooperation with the Equatorial Scatter program. There was also in existence the circuit between Havana, Illinois and Boulder, Colo., operating at frequencies of $30.010,49.605$, and 73.88 Mc. This latter circuit has been a good comparison circuit for the others. All stations had 5-element Yagi antennas.

The first test measurements were obtained during September 1957 on both the Panama to Guantanamo circuit and the Poro Point to Onna circuit and both circuits became officially operative on 1 October 1957. The Havana, Mlinois to Boulder, Colorado circuit became operative by November 1957. Essentially two experiments were performed during the IGY period; the regular sporadic- $E$ type of observations and a special pulsed $F$-layer scatter experiment.

The expected fact that sporadic $E$ is more intense in the Far East than in the Americas has been borne out. From the statistics gathered during the year sporadic $E$ of moderate intensity would appear to be approximately 2 to 3 times as frequent between the Philippines and Okinawa as between Panama and Cuba or Panama and Ecuador.

As the observations progressed it was realized that the considerable enhancements taking place during evening hours might be due to scatter from the $F$ region. At $50 \mathrm{Mc}$ the signal often rose 30 to $40 \mathrm{db}$ above the normal scatter signal level. During the IGY period the signal enhancement at 49.84 Mc showed an autumnal high with intermittent enhancement during the remainder of the year and a minimum during the vernal equinox. During the year, May 1956 to May 1957, over a circuit between the Philippines and Okinawa at $36.4 \mathrm{Mc}$, the evening anomaly showed a maximum during each equinoctial period. In order to verify the $F$-region origin for these anomalous signals a series of pulse measurements, giving range-time records, were carried out over the Philippines to Okinawa path during September 1958. Careful independent time standards were used to control the pulse repetition rate at the transmitting terminal and the oscilloscope sweep rate at the receiving terminal. The pulses were of $50 \mu$ sec duration, at a repetition rate $100 / \mathrm{sec}$, with a peak power of about $2 \mathrm{kw}$. When received, the pulses were spread over nearly a millisecond. The $F$-region scattered signals were readily distinguished from the normal E-region echo and showed a delay time relative to the $E$ region signal between 40 and $1200 \mu$ sec. Seldom were sporadic- $E$ signals between Panama and Cuba as strong as those in the Far East, despite the fact that in the Caribbean area the circuits spanned equivalent geomagnetic and geographic latitudes to those in the Far East.

A more detailed report of this Far Eastern VHF anomaly has been published [9]. These authors conclude that these anomalous signals are associated with low-latitude spread $F$ as often recorded by ionosphere sounders and may indicate the presence of field-alined blobs of ionization in the $F$ region.

\section{VHF Equatorial Forward Scatter Experi- ments}

Heretofore, experiments in VHF ionospheric forward scatter have been primarily conducted in north temperate latitudes and in the auroral zone, and not in the vicinity of the magnetic equator, where the ionosphere behaves differently and in a manner little understood. In this region are exhibited such phenomena as equatorial sporadic $E$, equatorial spread $F$, and a strong daytime currentsystem girdling the earth at the $100-\mathrm{km}$ level, known as the "equatorial electrojet". Amateur radio communications spanning the magnetic equator (e.g., between Buenos Aires and Mexico City) have been sustained on the $6-\mathrm{m}$ band (near $50 \mathrm{Mc}$ ) during evening hours of equinoctial periods at times of sunspot maximum, suggesting unusual ionospheric conditions in the equatorial zone.

To provide a systematic study of ionospheric irregularities and other effects which might support ionospheric propagation at $50 \mathrm{Mc}$ across the magnetic equator, an IGY experiment was set up in South America with circuits as illustrated in figures 10 and 11. A basic $E$-scatter circuit was installed between Arequipa and Trujillo, Peru, while the long-distance circuit between Antofagasta, Chile and Guayaquil, Ecuador was operated to observe scattering associated with effects in the lower $F$ region. These circuits centered on the magnetic equator at Huancayo, recorded over a 1-yr period so as to enable the study of seasonal and diurnal variations as well as more rapid changes in the equatorial ionosphere. R. Cohen and K. L. Bowles, project leaders, have reported earlier [10], in some detail, the circuit arrangement and the objectives of the experiment, as well as some results of early data analysis [11]. The core of this experiment, the transmitting and receiving stations cited, was comprised of four field laboratory trailers, while the equipment installed at the cooperating laboratories in Huancayo, Clorinda, Argentina, and Sao Paulo, Brazil was housed in existing facilities. The westcoast observations began in November 1957, while the transcontinental ones were underway in April 1958, and all operations continued until 1 December 1958. The basic equipment for the forward scatter experiments consists of large rhombic antennas, high-powered (3 $\mathrm{kw}$ or $20 \mathrm{kw}$ interchangeable) transmitters, and sensitive narrow-band receivers. The transmitting stations at Antofagasta, Chile $(49.960 \mathrm{Mc})$, and Arequipa, Peru (49.920 Mc) and the receiving stations at Huancayo, Peru, Trujillo, Peru, and Guayaquil, Ecuador, employed 1000-ft rhombic antennas directed along the several greatcircle paths. One transmitting station, Huancayo, Peru (49.880 Mc), and the two receiving stations at Clorinda, Argentina, and Sao Paulo, Brazil utilized stacked pairs of 5-element Yagi antennas. The Huancayo installation also had a small low-powered 100-w transmitter feeding a Yagi antenna directed toward Guayaquil. This circuit is intended for detection of the sporadic $E$ between Huancayo 


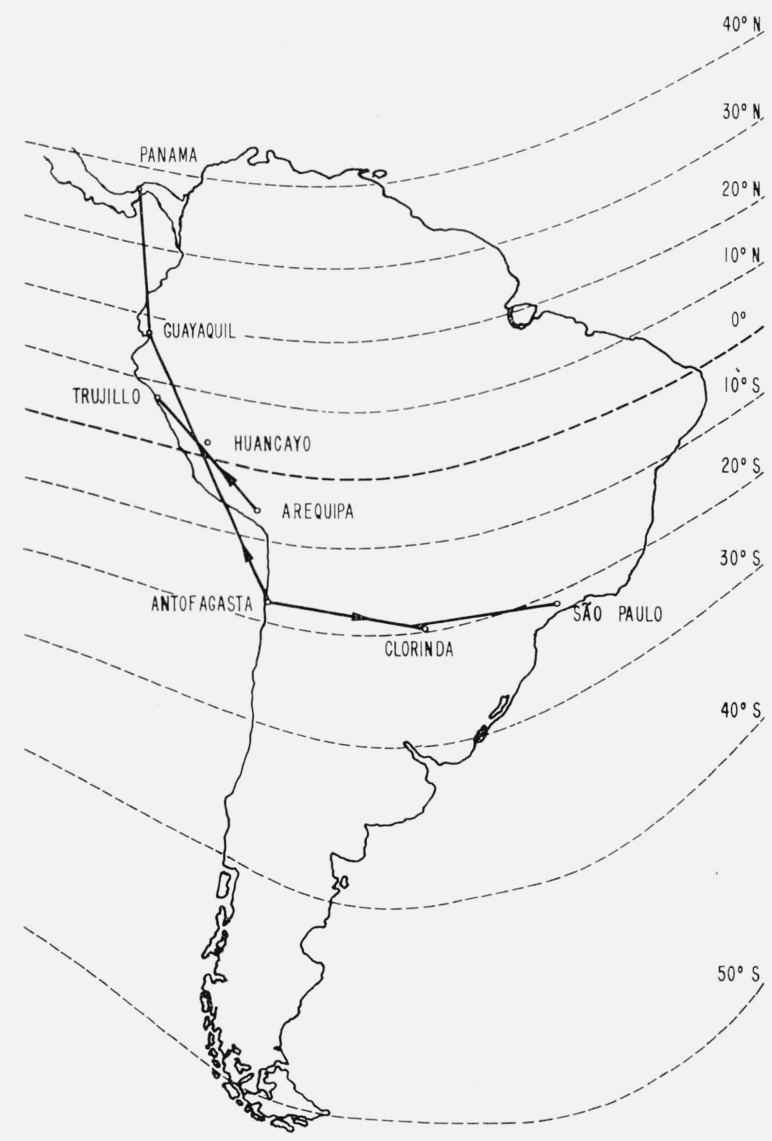

Figure 10. Map of South America showing the location of the equatorial forward scatter stations.

and Guayaquil. By using 100-cps bandwidth IF filters in the Guayaquil receiver, it proved possible there to record signals from Huancayo nearly 100 percent of the time, in spite of the low power. All receivers used a 12 -sec integration in the automaticgain-control circuit as a means of reducing the extreme variations on the chart due to normal fading. The quantity recorded was the AGC voltage, which is a good statistical estimator of the running median value of received signal power.

Two east-west circuits were installed along the $20^{\circ}$ isocline, to receive signals from Antofagasta at Clorinda, Argentina via the $E$ region and at Sao Paulo, Brazil via the $F$ region. These circuits were installed to compare equatorial east-west propagation, insofar as possible, with the north-south propagation, as well as to check on the southern range of latitude over which equatorial effects are encountered. The presence of transmitters and receivers appropriately spaced permitted the reception of signals at Huancayo from Antofagasta, at Trujillo from Antofagasta, at Guayaquil from Arequipa in addition to the basic circuits previously mentioned and the Huancayo-Guayaquil circuit. Thus there are three symmetrical $E$-scatter paths,

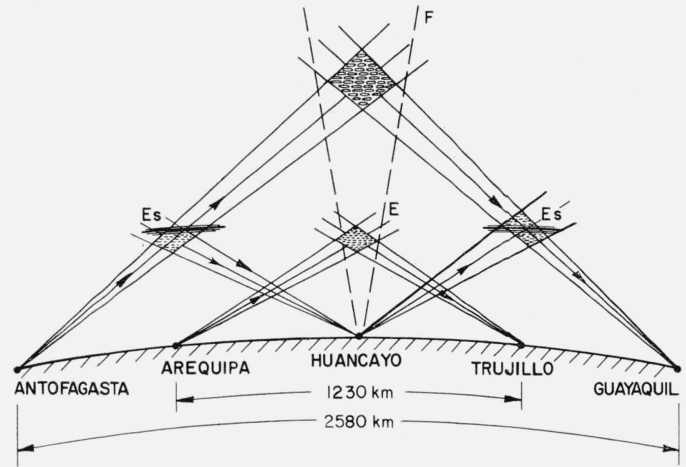

Figure 11. Cross section of the equatorial forward scatter circuits in South America.

as well as two asymmetrical paths, which permit the simultaneous observation of E-region effects at various latitudes. Ionospheric effects in this extensive region near the magnetic equator are particularly sensitive to latitude. Further details concerning the same ionospheric regions are provided by the records from the close-spaced chain of ionospheric sounders along the west coast of South America.

A preliminary comparison of the records obtained over the six circuits along the west coast of South America shows a number of interesting results; however, the complete picture will only be understood after a thorough analysis has been made. Over the two paths, Antofagasta to Guayquil and Arequipa to Trujillo, the short-term daytime variations in the signal intensity appear to correlate very closely. Indeed, over all six circuits, the day time signal traces appear to correlate reasonably well while nighttime correlations are poor. Comparisons with the vertical incidence soundings at Huancayo suggest that these daytime signals result from scattering by equatorial sporadic $E$. A close correlation exists, during certain periods studied, between the signal over the Arequipa to Trujillo path and the $H$ component of the Huancayo magnetogram. This is particularly the case when the signal correlation over all six paths is good. Since the $H$ component has been interpreted as a measure of the equatorial electrojet, a close relationship is now indicated between VHF signals and the electrojet, and perhaps also between equatorial sporadic $E$ and the electrojet. The Antofagasta to Huancayo and the Huancayo to Guayaquil records both show sporadic $E$ signals similar to those over circuits in middle latitudes, while the curious aspect is that the circuit from Arequipa to Trujillo almost never exhibits this form of sporadic $E$ propagation.

Often during the evening and nighttime hours on the Antofagasta to Guayaquil path (but not on the Antofagasta to Trujillo path) there is observed a strong signal increase which appears to correlate well with the occurrence of spread $F$ on the vertical incidence sounder at Huancayo. While it had been expected that $F$-region scatter might take place over 
this long-path circuit much of the time, this is evidence that it can occur at night.

The cooperation and participation of the IGY committees of Argentina, Brazil, Chile, Ecuador, and Peru was an indispensible part of this experiment, and the assistance by the government of these countries was greatly appreciated.

\section{IGY Radio Noise Network}

Radio noise is the basic limitation to radio reception, and in particular, the background of radio noise originating from natural causes in the atmosphere is often a severe restriction to good radio communication. Therefore, a detailed knowledge concerning the distribution of noise levels throughout the world and an understanding of the noise characteristics is fundamental to the advancement of communication techniques. For this reason, during the IGY, a worldwide network of stations recording radio noise levels was put into operation by NBS under the supervision of W. Q. Crichlow, R. T. Disney, and C. A. Samson.

In any radio noise measurements the following three parameters are useful: (1) The mean power, (2) the mean envelope voltage, and (3) the mean logarithm of the envelope voltage. The mean power averaged over several minutes is the basic parameter, and is expressed as an effective antenna-noise figure, defined as the noise power available from an equivalent lossless antenna in decibels above the thermalnoise power available from a passive resistance. Measurements of these parameters were made with the NBS radio-noise recorder, Model ARN-2, which has an effective bandwidth of 150 to $300 \mathrm{cps}$ and uses a 21.75 -ft vertical antenna and elevated groundplane system. There are eight channels used between $13 \mathrm{kc}$ and $20 \mathrm{Mc}$, two channels being recorded simultaneously. A 15 -min recording is made on each frequency each hour, and is taken as representative of the noise condition throughout the hour. In addition to measurements made with the $A R N-2$ in the worldwide network instantaneous amplitude probability distributions were obtained at Boulder, Colo. These distributions provide information concerning the detailed character of the noise from which its interference properties can be determined.

Preliminary results would indicate that the worldwide predictions as presented by the CCIR report No. 65 are too simplified. The behavior of radio noise, as a function of the frequency, time of day and season, differs widely from location to location. Specific local conditions need to be well understood in order to make accurate predictions.

As a few examples of this one can point out the following. Afternoon noise levels in areas of high local thunderstorm activity may be 20 to $30 \mathrm{db}$ higher than indicated by the predictions. Boulder, Colorado is a good example of this, since it is located near one of the most active thunderstorm regions in the United States - the front range of the Rocky Mountains. On certain days the variation may be as much as $70 \mathrm{db}$, on some frequencies. In contrast, at Kekaha in the Territory of Hawaii, the minimum noise levels for the low frequencies tend to occur near sunset instead of a few hours after sunrise as at most stations. As a result, the $160-\mathrm{kc}$ afternoon noise levels appear to be 20 to $30 \mathrm{db}$ lower than predicted at this location. The nighttime noise levels at Boulder are often lower than predicted while at Kekaha they agree rather well with the predictions.

The data recorded during the IGY at the stations listed in table 2 have been published in IGY data booklets and quarterly summaries have been issued as NBS reports giving trends and tentative conclusions

Table 2. Radio noise stations

\begin{tabular}{|c|c|c|}
\hline Stations & \multicolumn{2}{|c|}{$\begin{array}{l}\text { Geographic } \\
\text { coordinates }\end{array}$} \\
\hline & Latitude & Longitude \\
\hline Balboa, C.Z ..... & $9.0^{\circ} \mathrm{N}$ & $79.5^{\circ} \mathrm{W}$ \\
\hline Bill, Wyo _..... & $43.2 \mathrm{~N}$ & $105.2 \mathrm{~W}$ \\
\hline Boulder, Colo & $40.1 \mathrm{~N}$ & $105.1 \mathrm{~W}$ \\
\hline Byrd Station, Antarctica. & $80.0 \mathrm{~S}$ & $120.0 \mathrm{~W}$ \\
\hline Cook, Australia ......... & $30.6 \mathrm{~S}$ & $130.4 \mathrm{E}$ \\
\hline Enköping, Sweden & $59.5 \mathrm{~N}$ & $17.3 \mathrm{E}$ \\
\hline Front Royal, Va... & $38.8 \mathrm{~N}$ & $78.2 \mathrm{~W}$ \\
\hline Ibadan, Nigeria & $7.4 \mathrm{~N}$ & $3.9 \mathrm{E}$ \\
\hline Kekaha, Kauai, T.H. & $22.0 \mathrm{~N}$ & $159.7 \mathrm{~W}$ \\
\hline Ohira, Japan .............. & $35.6 \mathrm{~N}$ & $140.4 \mathrm{E}$ \\
\hline Pretoria, U. of S. Africa. & $25.8 \mathrm{~S}$ & $28.3 \mathrm{E}$ \\
\hline Rabat, Morocco & $33.9 \mathrm{~N}$ & $6.8 \mathrm{~W}$ \\
\hline São Jose dos Campos, Brazil_ & $23.3 \mathrm{~S}$ & $45.8 \mathrm{~W}$ \\
\hline Singapore, Malaya............ & $1.3 \mathrm{~N}$ & $103.8 \mathrm{E}$ \\
\hline Thule, Greenland.... & $76.6 \mathrm{~N}$ & $68.7 \mathrm{~W}$ \\
\hline
\end{tabular}

\section{Radio Satellite Observations at NBS}

Within $12 \mathrm{hr}$ of receiving the announcement on 4 October 1957 concerning the launching of Sputnik I, two groups at the Central Radio Propagation Laboratory, under the direction of R. S. Kirby, J. M. Watts, and R. S. Lawrence, had modified certain existing pieces of equipment to receive the 20- and 40-Mc signals from the first artificial earth satellite. Soon thereafter, a third group, under the direction of J. W. Herbstreit and M. C. Thompson, Jr.[12] made measurements using a continuous phasedifference measuring technique developed earlier for studying atmospheric turbulence in the troposphere. The instrumentation consisted of two similar Hamerlund SP-600 receivers operating on 20 (or 40) Mc. Continuously recording phase meters were used which compared the af tones from the two receivers. At first, half-wave dipoles were used, but later circularly polarized antennas were employed. Two effects were contained in the records: regular geometrical changes such as those related to the orbit and irregular changes presumably related to ionospheric turbulence and refraction. The group under R. C. Kirby and J. M. Watts used dipole antennas to measure the field intensity on 20 and $40 \mathrm{Mc}$ from which it was estimated that the total power emitted by Sputnik I was of the order of $1 \mathrm{w}$. This value was later confirmed by the Soviet scientists. The group under the direction of R. S. Lawrence and E. R. Schiffmacher modified the receivers in the $40-\mathrm{ft}$ dishes used for the radio star scintillation measurements in order to receive the $40-\mathrm{Mc}$ satellite 
signal. The two dishes are separated by a spacing of $1,500 \mathrm{ft}$. Within a few hours, dipole antennas were set up at twice the spacing of the dishes in order to receive the $20-\mathrm{Mc}$ signal on an electrically equivalent baseline. The phase-switching and detecting equipment, that had previously been used for the Jupiter project, was put in operation here. Measurements were made of the direction of arrival of the 20 and $40 \mathrm{Mc}$ signals. Simple ionospheric theory suggests that simultaneous measurements of refraction, at 20 and $40 \mathrm{Mc}$, should be in the ratio of 4 to 1 . If this were correct, simultaneous measurements on the two frequencies could be used to deduce the true satellite direction. Observations have shown, that in fact, the irregular structure of the ionosphere invalidates this procedure.

Following the initial "crash" prcgram more permanent interferometer arrangements were made at Table mesa near Boulder. Pairs of half-wave dipoles, with horizontal east-west polarization at one third wave length above the ground, were set up at the corners of equilateral triangles of $3,000-\mathrm{ft}$ and 150 -ft spacing. Observations were made at both 20 and $40 \mathrm{Mc}$. In addition circularly polarized antennas were installed. The output can be recorded on magnetic tape or on two 6-channel Sandborn recorders. The equipment is fully automatic and can be set for automatically coming on during the passage of a satellite beacon transmitter at these frequencies. Two Yagi antennas on a frequency of $108 \mathrm{Mc}$ have also been installed and a vertically polarized antenna for $20 \mathrm{Mc}$. The satellite ionospheric measurements program at the National Bureau of Standards is now under the direction of C. G. Little. With this arrangement of antennas measurements of angle of arrival, Faraday rotation, polarization, scintillation, diversity effects, and Doppler frequency changes have been made.

Inspection of the Faraday fading records of the 20 Mc signals made during the first 4 months of satellite $1958 \delta$ show the following systematic variations in the fading rate: (a) The fading rate is slowest when the satellite is in the north and greatest when it is in the south; (b) the greater height of the satellite during the north-to-south passes, and hence the longer ionospheric paths of the radio signals, accounts for the greater fading rates during these passes than during the south-to-north passes; (c) nighttime passes are characterized by a fading rate that is much slower than for daylight passes at the same height. When the fading rate was compared with the square of the $F$-layer critical frequency, taken from the Boulder ionograms, it shows that the daily variations in fading rate are largely due to the daily variations in the ionization content of the ionosphere. Many of the Faraday-rotation rates, rather than varying smoothly throughout a single passage of the satellite, vary irregularly and indicate the existence of ionospheric irregularities. In some instances these irregularities are of the order of $100 \mathrm{~km}$ in lateral extent. Calculations, using the $20 \mathrm{Mc}$ signal from $1958 \delta-2$, show that the observed irregularities in the Faraday rotation rate can be accounted for if the integrated electron content, along the line of sight, per square centimeter column, varies irregularity with variations of the order of $10^{9}$ during a $1-\mathrm{km}$ change (horizontal) in satellite position. From a determination of the number of complete rotations of the plane of polarization of the radio signal, the total electron content, up to the height of the satellite, can be calculated. For a pass of satellite $1958 \delta-2$, at a height of about $236 \mathrm{~km}$, low in the $\mathrm{F}$ region, the integrated electron content in a vertical column was estimated as $2.7 \times 10^{12}$ electrons $/ \mathrm{cm}^{2}$ column.

In conjunction with the satellite observations a computer program is being set up for tracing the paths of the rays between the satellite and the receiver. The ordinary and extraordinary rays are traced separately through the ionosphere and the difference in their phase paths gives the instantaneous orientation of their polarization vector. Actual ionospheric profiles from ionograms are used up to the $F$-region peak, but various assumed profiles are tried for the upper ionosphere. The ray-tracing program is coupled to a program which gives successive positions of the satellite along an elliptical orbit. The combination of these two programs gives a complete picture of the Doppler frequency, the Faraday rotation, and the angle of arrival of the satellite signal. A comparison between the direction of arrival and line of sight to the satellite gives a measure of the angular errors introduced by the ionosphere.

\section{Airglow Observations}

The atoms and molecules of the earth's upper atmosphere continuously radiate a flux of light and radiation. During the daylight hours this flux is swamped by a much stronger energy flux from the sun, but at night the airglow emitted from the high atmosphere can be easily detected by sensitive photometers and on occasion it can be seen by the human eye. Closely related to the airglow emission, and perhaps a part of the same phenomenon, is the well known and often observed aurora associated with high-latitude belts on the earth. Because of its wide distribution and constant occurrence, it was logical that a worldwide study of the airglow be undertaken as a part of the IGY synoptic program. F. E. Roach has directed the NBS airglow program involving observation stations at Fritz Peak, Colorado and Rapid City, South Dakota. In addition, the group constructed photometers for College, Alaska, Huancayo, Peru, and Sidney, Australia. The photometer itself is of a hybrid design combining the Lyot birefringent filter principle, as adapted by J. Blamont and A. Kastler [13] and used by R. B. Dunn and E. Manring [14] with the telescope system designed by F. E. Ross. The telescope has a 6 -in. objective, a focal length of $13 \mathrm{in}$., and a 4-degree field of view. A series of color filters permit the selection of one of the following emissions characteristic of the night airglow: OI $\left({ }^{1} \mathrm{~S}_{0}-{ }^{1} \mathrm{D}_{2}\right)$ at $5577 \mathrm{~A}$, OI $\left({ }^{1} \mathrm{D}_{2}-{ }^{3} \mathrm{P}_{1}\right)$ at 6300 $\mathrm{A}$, and $\mathrm{NaI}\left({ }^{2} \mathrm{P}_{3 / 2}-{ }^{2} \mathrm{~S}_{1 / 2},{ }^{2} \mathrm{P}_{1 / 2}-{ }^{2} \mathrm{~S}_{1 / 2}\right)$ at 5890 and $5896 \mathrm{~A}$. In addition there are many strong bands of emission 
in the infrared from the $\mathrm{OH}$ molecule. The photometer is programmed to sweep the sky in successive almucanturs at angles of $80^{\circ}, 75^{\circ}, 70^{\circ}, 60^{\circ}, 40^{\circ}$, and the zenith. The photometer sweeps the entire sky in $4 \mathrm{~min}$ at each wavelength and returns once each 15-min interval to repeat the wavelength sequence. The data are recorded on a strip chart recorder and transferred to punch cards for processing on the IBM 650 .

In addition to the photometer described above, a simple photometer of the Roach-Elvey type was installed at Thule, Greenland in October 1958 for special observations at the magnetic pole. There was also installed an all-sky camera and a patrol spectrograph at Fritz Peak and at Rapid City.

A number of notable results have come from this IGY airglow program at the Central Radio Propagation Laboratory. Since a number of publications have appeared describing these results they will only be referred to here and not described in detail.

An analysis of the nightglow observations at 5577 A shows the emission to come from a height of approximately $100 \mathrm{~km}$ [15]. Direct measurements of the altitude of the night airglow obtained from rockets [16] show the maximum of the 5577-A layer to be near $98 \mathrm{~km}$. Systematic isophote airglow maps of the night sky throughout many nights have been prepared and a careful analysis of these maps made. This analysis shows the sky to contain discrete airglow cells of 5577-A emission, having a characteristic diameter of $2500 \mathrm{~km}$ and moving with translational speeds of about $100 \mathrm{~m} / \mathrm{sec}$. These airglow cells appear to exhibit a rotational period of about $5 \mathrm{hr}$.

In order to investigate the possibility that the 5577-A night airglow, present over the earth as a whole, may be closely related to the aurora, which is prevalant in high-latitude regions, the CRPL investigators have made a statistical analysis concerning the frequency of occurrence of these phenomena [17, 18]. Although this type of statistical treatment is open to some question it may give a clue as to whether or not these two phenomena, the airglow and the aurora, have a common origin.

\section{World Data Center A-Subcenter for Airglow and Ionosphere}

Located in the Boulder Laboratories of the National Bureau of Standards is the United States IGY, World Data Center A, Subcenter for Airglow and Ionosphere Data. The Data Center is under the supervision of W. B. Chadwick and S. M. Ostrow. To this subcenter, all airglow and ionospheric stations in the western hemisphere and Australia and New Zealand send their data for copying and filing. In this manner, a central file of the results of the IGY observations will be made available for research and study for many years to come. It was the responsibility of this subcenter during the IGY to send or arrange to be sent copies of the data to World Data
Centers B, C1, and C2 located in the USSR, England, and Japan respectively. These centers in return send data from the laboratories in their area of responsibility to Boulder. This subcenter, in addition to maintaining files of the data, prepares catalogues and indexes of the data, makes copies of the data available to scientists, organizations, and others requiring its use, and maintains at the Data Center office space where visiting research workers can come for study.

Although not all stations supply the same amount of data to the Data Center, the following items were contained in the recommendations of the First Report of the Special Committee on Worldwide Soundings:

1. Hourly values of $f_{0} F_{2}, h^{\prime} F_{2},(\mathrm{M} 3000) F_{2}, f_{0} F_{1}, h^{\prime} F,(\mathrm{M} 3000) F_{1}, f_{0} E, h^{\prime} E$, $F$-min, $f_{0} E \mathrm{~s}, f b E \mathrm{~s}, h^{\prime} E \mathrm{~s}$, and other types of $E \mathrm{~s}$.

2. All median values of $f_{0} F_{2},(\mathrm{M} 3000) F_{2}$, and $f_{0} E \mathrm{~s}$ and other median values.

3. All stations were to produce $f$ plots for Regular World Days, Special World Intervals, and any other occasions on which quarter-hourly or more frequent observations are scaled. High-latitude stations and a number of other key stations were to supply $f$ plots for every day.

4. Ionograms at least for the Regular World Days and Special World Intervals.

In addition, other special types of data will eventually be on file in the Data Center, such as whistler data, radio-noise data, equatorial forward-scatter data, and data from other unique experiments. For the airglow studies zenith-intensity digital data for several stations, for the oxygen emissions at $5577 \mathrm{~A}$ and $6300 \mathrm{~A}$, sodium at $5893 \mathrm{~A}$, and the near infrared $\mathrm{OH}$ emission, is coming into the Data Center. The stations included in the American chain are Thule, Saskatoon, Rapid City, Fritz Peak in Colorado, Sacramento Peak in New Mexico, Tantazantla and Huancayo, Peru.

A steady flow of data has been coming in to the Data Center during the latter part of the IGY and it will be more than a year after the close of the IGY period before most of the data is in. The Data Center has received sizable amounts of data from the other World Data Centers. In addition to the IGY data, the Data Center has available in Boulder an extensive archive of data covering many years of records from stations throughout the world.

Workers desiring data may obtain it for the cost of reproduction from the World Data Center A, Subcenter for Airglow and Ionosphere, Central Radio Propagation Laboratory, National Bureau of Standards, Boulder, Colorado.

The author wishes to express his appreciation to the project leaders and others for their assistance in the preparation of this article. 


\section{References}

[1] R. W. Knecht and D. W. Schlitt, Early results from the equatorial close-space chain of ionospheric vertical soundings stations, Proceedings of the Vth CSAGI Assembly, (Moscow 1958), Annals of the IGY.

[2] K. G. Budden, A method for determining the variation of electron density with height $(\mathrm{N}(\mathrm{z})$ curves) from curves of equivalent height versus frequency $\left(h^{\prime}, f\right)$ curves, Rept. Cambridge Conf. Ionospheric Phys. p. 332 (Phys. Soc. London 1954).

[3] E. K. Smith, Worldwide occurrence of sporadic E, NBS Circ. 582, March (1957).

[4] S. Matsushita, Intense Es ionization near the magnetic equator, J. Geomagnetism and Geoelectricity 3, 44 (1951).

[5] H. Odishaw, International Geophysical Year, Science 128, 1599 (1958).

[6] S. Matsushita, Lunar effects of the equatorial Es, J. Atmospheric and Terrest. Phys. 10, 163 (1957).

[7] R. W. Knecht, submitted for publication, Journal of Atmospheric and Terrest. Phys.

[8] R. W. Knecht, R. E. McDuffie, and Y. Aono, Preliminary results from U.S.-IGY antarctic network of ionospheric vertical soundings stations, Proc. of the Vth CSAGI Assembly, Moscow, Aug. (1958) Annals of the IGY.

[9] R. Bateman, J. W. Finney, E. K. Smith, L. H. Tveten and J. M. Watts, International Geophysical Year observations of F-layer scatter in the Far East, J. Geophys. Research 64, (1959).
[10] K. L. Bowles, and R. Cohen, NBS equatorial region vhf scatter research program for the IGY, QST, $\mathbf{4 1}$, 11-15 (August 1957).

[11] R. S. Cohen, and K. L. Bowles, 50-Me oblique transmission experiment near the magnetic equator, Presented to URSI-IRE Spring Meeting, Washington, D.C. (1958).

[12] J. W. Herbstreit and M. C. Thompson, Jr., Continuous phase difference measurements of earth satellites, Proc. IRE 46, 1535 (1958).

[13] J. Blamont and A. Kastler, Réalisation d'un photomètre photoélectrique pour l'étude de l'émission crépusculaire de la raie d du sodium dans la haute atmosphère, Ann. géophys. 7,73 , (1951).

[14] R. B. Dunn and E. R. Manring, A recording night sky photometer of high spectral purity, J. Opt. Soc. Am. 45, 899 (1955).

[15] F. E. Roach, L. R. Megill, M. H. Rees, and E. Marovich, The height of nightglow 5577, J. Atmospheric and Terrest. Phys. 12, 171 (1958).

[16] R. Tousey, Rocket measurements of the night airglow, Ann. géophys. 14, 186 (1958).

[17] F. E. Roach, J. W. McCaulley, and E. Marovich, Origin of [OI] 5577 in the airglow and the aurora, J. Research NBS 63D, 15 (1959).

[18] F. E. Roach, J. W. McCaulley, and C. M. Purdy, Comparison of absolute intensities of [OI] 5577 auroral and subauroral zones, J. Research NBS 63D, 19 (1959).

Boulder, Colo. (Paper 63D1-1). 